\title{
DOES TRADE OPENNESS HAS NOTEWORTHY EFFECT ON BILATERAL TRADE FLOWS OF E.C.O. COUNTRIES; AN EMPIRICAL INVESTIGATION
}

\author{
Ali GULZAR 1
}

DOI: 10.1515/tjeb-2016-0007

\begin{abstract}
This study empirically investigated the effect of trade liberalization on the bilateral trade flows of ${ }^{2}$ ECO (Pakistan, Turkey and Iran) countries using annual time series data for the period of 1980-2016. The study applied unit root test, bound testing approach and ARDL regression analysis technique to empirically examine the role and impact of trade openness on bilateral trade flows of ECO countries. The empirical results found long-run positive and significant effect of trade openness on bilateral trade flows of ECO countries. Further, the study concluded that trade openness playing an important role in exports as well as in fulfilling the requirements by imports. The findings of the study might provide significant guidelines to policy makers to initiate rules and regulations for the improvement in international trade that might help in attainment of sustainable foreign exchange reserves and economic growth of ECO countries.
\end{abstract}

Keywords:

E.C.0. Countries, Bilateral Trade, ARDL regression analysis, diagnostic \& stability analysis

JEL Classification:

1 Research Scholars, School of Economics, Huazhong University of Science \& Technology, Wuhan, Hubei, P.R China \& Department of Economics, Islamia College University Peshawar, KPK, Pakistan.

2 Economic Cooperation Organizations formally known as RCD (Regional Cooperation for Development). 
Gulzar, A. (2016).

DOES TRADE OPENNESS HAS NOTEWORTHY EFFECT ON BILATERAL TRADE FLOWS OF E.C.O. COUNTRIES; AN EMPIRICAL INVESTIGATION

\section{Background of the Study}

Trade liberalization or trade openness plays a vital role in the economic development of any nation and could notably be called growth locomotive. Free trade or trade liberalization consists of strategies that support trade without quantitative and qualitative restrictions across international boundaries, where trading allies are permitted by the policy to have mutual benefits from the trade exactly according to the law of comparative advantage. Trade liberalization consists of policies of complete or partial removal or reduction of tariffs and non-tariff restrictions and barriers on the free exchange of capital, services and goods globally to promote "free trade". Today, most of the developing and developed countries approved the policy of trade liberalization through the diminution or complete eradication of trade barriers. Popular trade barriers adopted since last few decades are import and export tariffs, export subsidies, technical barriers and quotas. Time has witnessed great economic developments and sharp changes in living standards. This development can be attributed towards globalization and liberalization of international trade due to technological developments and concerted efforts to reduce trade barriers.

Trade liberalization or Trade Openness has direct and indirect positive effects on economic growth by enhancing technological transfers, productivity, infrastructure, investment, market exposure, employment, mobility of factors, etc. Trade openness increase economic growth and support quality production by providing access to a competitive environment for investment and industrial production. However for less developed conventional economies which mostly depend upon agriculture sector the export performance didn't nourish under trade liberalization. The main reason behind this is the concentration of economic growth on agriculture output which is interconnected to climatic and periodic conditions and usually has high risk of uncertain agro-production unlike industrial production.

Trade liberalization policies enhance the production yield of economy and encourage specialization by producing those commodities in which country have comparative advantages. Furthermore exchange of information, technology and quality enhances the competition and overall productivity. Trade openness has great potential to create new investment opportunities by providing free mobility of capital. Open economies are more capable to utilize economies of scale and directed to large scale investment requisite to less developed nations.

DE GRUYTER OPEN
Timisoara Journal of Economics and Business | ISSN: 2286-0991 | www.tjeb.ro Year 2016 | Volume 9 | Issue 2 | Pages: 95-114 
Gulzar, A. (2016).

Geographically Pakistan is surrounded by landlocked countries like Afghanistan and the Central Asian States. Pakistan plays a vital role as trade transit trade for smooth and rapid courses of trade across borders. To improve transit trade traffic through the region Pakistan is in compliance with the historic Transit Trade Agreement with Afghanistan, as well as other transit agreements has been established with different countries like the Transit Trade Framework Agreement with ECO countries and a Quadrilateral Agreement with China, Kyrgyzstan, Kazakhstan, are being implemented following the rules of WTO (GATT Article V).

The effect of trade liberalization on bilateral trade is uncertain and ambiguous due to its diverse impact on different sectors and capital intensiveness of industry which works both ways increasing and decreasing bilateral trade through enhancement of production activities and labor substitution mechanism. This study aims to empirically investigate the effect of trade liberalization on bilateral trade of ECO countries. These countries have similar religious, customs and traditions as well as closely bound with many trade agreements. But from several decades these countries have facing several challenges that also effects their bilateral trade and investments. That's why this study will not only add to existing literature but also some valuable suggestions for policy makers to enhance bilateral trade among these countries. Further, this study will also emphasize to find the causal link among the bilateral trade of study countries.

This study will be great assistance for understanding the role of trade openness in economic development and growth of ECO Countries. International trade and economic growth are interrelated phenomenon, increase in economic growth creates surplus output that leads to increase export earnings and thus that foreign exchange is utilized in purchasing imports. In short economic growth leads to higher trade earnings while at the same time foreign trade contribution improve economic growth and development. So this study highlights the main factors affecting these two crucial macroeconomic variables and their impact on each other as well.

Being struggler in the race of the world economies, ECO countries has to adopt liberalization police to pace up its development and grab the advantages of free international market. But at the same time it's a less develop country with poor industrial base and has to protect domestic industry by providing incentives in the form of subsidies as well as protection in the form of import quotas and tariffs. The study will focus on providing suggestions to tackle this issue by signifying advance measures of trade liberalization which would nourish economic growth and domestic investment under free trade environment by doing so both quantity and quality of overall economic output could be enhanced. The study will hopefully

DE GRUYTER OPEN
Timisoara Journal of Economics and Business | ISSN: 2286-0991 | www.tjeb.ro Year 2016 | Volume 9 | Issue 2 | Pages: 95-114 
Gulzar, A. (2016).

DOES TRADE OPENNESS HAS NOTEWORTHY EFFECT ON BILATERAL TRADE FLOWS OF E.C.O. COUNTRIES; AN EMPIRICAL INVESTIGATION

provide guideline and will benefit future researcher, micro and macroeconomic agents and policy makers.

\section{Literature review}

Generally perceived that trade liberalization or trade openness have noteworthy effect on the international trade as well as generate a competitive environment for the countries to improve the quality and quantity of the products to enhance increase in their exports and foreign trade (Ravallion, 2004). Openness of trade is one of the apparent characteristics of economic growth and definitely an important element to its defining distinctiveness. That's why many researchers have attempted to evaluate the effects and importance of trade openness in economic growth. Mixed literature been exists regarding to trade openness and its possible effect. Some empirical studies support positive effect, some negative while some studies didn't found any significant effect of trade openness or liberalization policies. Some of the economist suggests that developing countries can gain much from international trade, while other have doubtful believe on the gain from foreign trade.

This study is different in two ways; firstly, a vast number of studies exist on the role of trade openness in different countries, but none of the study on ECO countries. Secondly, approximately all of the studies focused on the effect of trade openness in economic growth, but this study evaluating the role of trade openness in bilateral trade flows of ECO countries. This topic is gaining much interest because foreign trade is the active element of growth and development and those countries whose international trade is high (i.e. China, Germany, France, Korea, Japan, USA etc.) their growth is also high. That's why this study is focusing on the role of trade openness in bilateral trade flows of ECO countries as these countries are strongly linked with each other by politically, socially, religiously, morally and economically. A brief description of some of the past literature regarding to trade openness and bilateral trade flows are given below.

Vedpal and Sudesh (2004) examined the long run relationship between trade openness and economic growth for India. The study used cross sectional data covering the period of analysis from 1951-2002. In methodology of the study Vector Auto Regressive (VAR) model, Error Correction Model (ECM) and Granger Causality test were used to find out long run relationship between trade openness and economic growth. The study found significant and positive long run relationship between trade openness and economic growth with increasing performance of growth for India.

DE GRUYTER OPEN
Timisoara Journal of Economics and Business | ISSN: 2286-0991 | www.tjeb.ro Year 2016 | Volume 9 | Issue 2 | Pages: 95-114 
Gulzar, A. (2016).

DOES TRADE OPENNESS HAS NOTEWORTHY EFFECT ON BILATERAL TRADE FLOWS OF E.C.O. COUNTRIES; AN EMPIRICAL INVESTIGATION

Dritaski and Adamopoulos (2005) investigated the impact of trade openness, exports and imports on economic growth of Greece. The study used annual time series data for the period of analysis from 1960-2002. In methodology of the study co-integration method was used to examine the long run relationship between exports, imports, Foreign Direct Investment (FDI) and economic growth. The results obtained from the regression analysis of the study revealed that Foreign Direct Investment (FDI), exports and foreign trade had positive significant impact on long run economic growth of Greece maintaining their smooth and steady state level. Dritsaki (2004) attempted to analyze the relation between exports, investment and economic growth among European Unions, Bulgaria and Romania applying co-integration, Granger Causality and multi-variate Vector Auto-Regressive (VAR) Model. The result indicates that there is strong causal relation among exports, investment and economic growth of these countries. Dritsaki and Adamopoulos (2004) investigated the causal relation between foreign trade, Foreign Direct Investment (FDI) and economic growth for Greece using time series data from 1960-2002. The study found long-run causal relation among trade, foreign direct investment (FDI) and economic growth applying Johansen co-integration and Granger Causality test. Dritsaki, Vazakides and Adamopoulos (2004) empirically examined the effect of exports and investment on economic growth for three 3BALTIC Countries using panel data from 1992: I - 2000: IV. The study found encouraging long-run effect of exports and investment on economic growth of BALTIC countries applying co-integration test and tri-variate Vector Auto-Regressive (VAR) Model.

Adebiyi and Ros (2006) empirically investigated the relationship between trade openness, trade policies and economic growth of Nigeria. The annual time series data was used in the study covering the period of analysis from 1970-2005. Vector Auto-Regressive (VAR) technique was applied in the methodology as analytical techniques. The results obtained from the regression analysis and estimation of variables reveals that trade openness had significant and positive impact on Nigeria's economic growth.

Achay (2006) studied trade flows among different countries of the world. The study used panel data for the five sub-periods on yearly basis from 1970-2000. In methodology of the study Trade Gravity Model was applied to find out trade flows relationship among 126 different countries of the world. The results obtained from the study showed that bilateral trade flows had positive and significant impact for these 126 selected sample countries with each other fetches to momentous increase in their growth from bilateral trade.

3 Estonia, Lativa and Lithunia

DE GRUYTER OPEN
Timisoara Journal of Economics and Business | ISSN: 2286-0991 | www.tjeb.ro Year 2016 | Volume 9 | Issue 2 | Pages: 95-114 
Gulzar, A. (2016).

Thai (2006) examined the bilateral trade flows among Vietnam and twenty-three (23) European Countries. The study based on panel data covering the period of analysis from 1993-2004. In methodology Trade Gravity Model was applied to empirically estimate trade potentials of Vietnam and its bilateral trade flows with selected sample of 23 European Countries. The results obtained from the regression analysis of the study indicate that economic growth, exchange rate and market size played noteworthy role in bilateral trade flows among Vietnam and its trading partners of European Countries.

Khan and Bashir (2007) examined the impact of trade labialization on economic growth of Bangladesh. The cross sectional data was used in the study covering the period of analysis from 1974-2002. In methodology of the study Johnson co-integration and Error Correction Model (ECM) were applied to empirically investigate short run and long run relationship among physical capitals, real interest rate, trade openness and economic growth of Bangladesh. The findings of the study revealed that physical capitals and real interest rate had significant and positive impact on Bangladesh's economic growth in long run, while financial liberalization in short-run. The study concluded that main reason behind long run failure of financial liberalization policies of government was that, the government of Bangladesh didn't attract foreign and new investment in their domestic investment. In policy recommendation they suggested that Bangladesh government should need to bring improvement in their infrastructure, way of governance, better and friendly climate for foreign investor and reforms in liberalization policies to get full fruit from trade openness.

Erdem and Nazliglu (2008) investigated the bilateral trade flows determinants of agriculture exports between Turkey and European countries. The panel data was used in the study covering the period of analysis from 1996-2004. In methodology of the study Trade Gravity Model was applied to explore and estimate the variables of bilateral trade flows for exports of agriculture sector of Turkey. The study found that agriculture exports of Turkey were positively correlated with European Union (EU) countries. The results obtained from the regression analysis of the study revealed the positive and significant effect of bilateral trade flows on imports population, Turkish's people living in European Union (EU) countries and size of the economies, whereas, negatively correlated with geographical distance and transportation's cost.

Ahmed (2010) estimated the role of trade openness in relation with institutional change and its effect on economic growth using panel data for 133 countries, taking period of analysis from 1985-2009. The growth model was used in the study and regressed through Generalized Method of Movement (GMM). The results revealed that trade openness and

\section{DE GRUYTER} OPEN
Timisoara Journal of Economics and Business | ISSN: 2286-0991 | www.tjeb.ro Year 2016 | Volume 9 | Issue 2 | Pages: 95-114 
Gulzar, A. (2016).

institutional change has robust affirmative and vital effect on economic growth especially for developing countries. The study also found significant effect of trade openness on the per-capita economic growth. Surprisingly, the co-efficient value of trade openness and institutional change were different when regressed on the real and current values of growth for the selected sample study countries.

Zaman, et. al., (2010) attempted to empirically examine bilateral trade impact between Pakistan and Turkey. The panel data was used in the study covering the period of analysis from 1990-2008. In methodology of the study Trade Gravity Model was applied to explore the bilateral trade flows between Pakistan and Turkey. The results obtained from the regression analysis of the study showed strong relationships between bilateral trade flows and economic growth for both Pakistan and Turkey and weak relationship between distance of these two countries and bilateral trade flows. In recommendations of the study they suggested that bilateral trade between these two countries needs more boost up and upgrading for achieving the prosperous economic growth.

Hsin-yi (2010) re-examined the impact of trade openness and inflation on economic growth of selected sample of one hundred and six (106) countries. The study used panel data for the period of analysis from 1970-2007. In methodology of the study Johnson co-integration and Vector Auto Regressive (VAR) model were applied for the estimation of results. The study found that trade openness has positive and significant impact on economic growth for selected sample of included studied countries. Further, the study also analyzed that inflation had negatively associated with trade liberalization and economic growth of these selected sample countries.

Malik and Chaudhary (2012) empirically analyzed the trade openness, trade policies, bilateral trade flows of exports and imports among some selected Asian countries and Pakistan. The study based on panel data over the period of analysis from 1996-2006. The Trade Gravity Model was used in the methodology and regressed through Generalized Least Square (GLS) method for the estimation of variables. The results obtained from the study revealed positive and significant impact of trade flows (exports and Imports) between Pakistan and selected sample study of Asian Countries. The exchange rate also played a crucial role in increasing and determining the exports and imports of Pakistan and selected sample of Asian countries. Further, the study examined that current year trade flows had strongly correlated with and affected by previous year trade flows.

\section{DE GRUYTER} OPEN
Timisoara Journal of Economics and Business | ISSN: 2286-0991 | www.tjeb.ro Year 2016 | Volume 9 | Issue 2 | Pages: 95-114 
Gulzar, A. (2016).

Ulasan (2012) empirically investigated the relationship between trade openness, international trade and long-run economic growth for Turkey using cross sectional data for the period of 1960-2000. For regression analysis the simple Ordinary Least Square (OLS) technique were used with applying instrumental variable. The model was double log to reduce the variance and error estimation in the data. The results showed positive and significant effect of trade openness and international trade on long run economic growth for Turkey. Further, the study suggested that in economic growth of Turkey the other variables like population density, institutions, geography and economic stability also played a major role.

Mercan, et. al., (2013) studied the impact of international trade and trade openness on economic growth of BRIC-T 4 countries. The study regress panel data and the period of analysis were from 1989-2010. The results of the study revealed that foreign trade (exports and imports) and trade openness had positive and significant effect on economic growth of these emerging countries.

Shaista, et. al., (2013) empirically investigated the bilateral trade flows of Pakistan with five (05) major trading countries.5 The study used panel data for the period of analysis from 1990-2010. In methodology of the study Trade Gravity Model was used for the analysis and estimation of the variables. The results obtained from the regression analysis of the study found positive and significant association between bilateral trade flows and Gross Domestic Product (GDP) of these countries. The results of the study also showed the negative impact of Distance and Dummy variables used for culture similarities on economic growth of these selected samples of countries.

Tabari and Haghight (2014) attempted to analyze the bilateral trade relationship among Iran and forty-five (45) Asian countries. The study was based on panel data covering the period of analysis from 2001-2011. In methodology of the study Trade Gravity Model was used and regressed with the help of Pooled Estimated Generalized Least Square (EGLS) based on Random effect and fixed effect Model. The results obtained from the regression analysis of the study revealed that bilateral trade flows of Iran had positively correlated with selected sample of 45 Asian countries leads to an increasing the Iran's exports and imports that have noteworthy impact on economic growth of Iran. Further, the study found that increase in real exchange rate has negative impact on the exports and positive on the

\footnotetext{
${ }^{4}$ Brazil, Russia, India, China and Turkey.

5 Japan, Turkey, Malaysia, India and Iran according to the researchers of the paper.
}

DE GRUYTER OPEN
Timisoara Journal of Economics and Business | ISSN: 2286-0991 | www.tjeb.ro Year 2016 | Volume 9 | Issue 2 | Pages: 95-114 
Gulzar, A. (2016).

DOES TRADE OPENNESS HAS NOTEWORTHY EFFECT ON BILATERAL TRADE FLOWS OF E.C.O. COUNTRIES; AN EMPIRICAL INVESTIGATION

imports of Iran. Due to fluctuation in exchange rate the exports of Iran decreases and its imports increases during the selected period of analysis of the study.

Elshehawy, et. al., (2014) investigated the bilateral trade flows and exports among Egypt and its trading partners (42 countries). The study was based on panel data for the period of analysis from 2000-2013. In methodology of the study Trade Gravity Model was applied to estimate the impact of exports for Egypt. The results obtained from the regression analysis of the study showed that exports of Egypt, regional trade and importer's population had positive and significant effect on Egypt's economic growth. The study also found the negative impact of transportations cost and geographical distances on the Egypt's economic growth.

\section{Econometric Model and Specification}

For the development of econometric model the idea was taken from the earlier studies of studies of (Burger, et. al., 2009; Kolstad, 2009; Mehlum, et. al., 2006; Santos, et. al., 2006; and Moulton, 1986). As this study aims to empirically investigate the role of trade openness on the bilateral trade of ECO countries, therefore, the model used consists of multiple properties of the variables i.e basic trade variables, proxy variables, characteristics variables and specification variables. The general form of the model is

$$
B T_{t}=\beta_{0}+\beta_{1} \omega_{t}+\beta_{2} \kappa_{t}+\beta_{3} \phi_{t}+\beta_{4} \theta_{t}+\eta_{t}
$$

Here BT represents bilateral trade among ECO (Pakistan, Turkey and Iran) countries, " $\omega$ " represents the basic growth variables, " $K$ " represents the proxy or dummy variables, and " $\varphi$ " represents characteristics variables and " $\theta$ " specification variables. " $t$ " represents the characteristics of data that is time series.

The general theoretical model following the model (1) for the ECO countries be in the form of

$$
B T=(X, M, T O P, E R, T O T)
$$


Gulzar, A. (2016).

DOES TRADE OPENNESS HAS NOTEWORTHY EFFECT ON BILATERAL TRADE FLOWS OF E.C.O. COUNTRIES; AN EMPIRICAL INVESTIGATION

Here, "BT" is the "bilateral trade, " $\mathrm{X}$ " are the exports of each ECO country, " $M$ " is the imports, "TOP" is the trade openness, "ER" is the real effective exchange rate and "TOT" is the terms of trade.

The econometric model following the theoretical model (2) is in the form of

$$
B T_{t}=\beta_{0}+\beta_{1} X_{t}+\beta_{2} M_{t}+\beta_{3} T O P_{t}+\beta_{4} E R_{t}+\beta_{5} T O T_{t}+\eta_{t}
$$

\section{Data Description and Analysis}

The data used in this study is annual time series data obtained from different sources i.e. World Data Indicator (WDI), Pakistan Bureau of Statistics, The global economy, World economy, World Bank and Trading Economics.

\section{Methodology, Results and Discussions}

Table (1) shows descriptive statistics and results of Jarque-Bera normality test for Pakistan, Turkey and Iran. Standard deviation is high in case of Turkey, medium in case of Pakistan and lower and close to mean value of Iran. Tough it is complicated to interpret the skewness value and it may be negative or positive and shows the probability of distribution of random or error term. The results integrated in table (1) indicate that the skewness in the data of Pakistan and Turkey is negative while positive in case of Iran. The results of JarqueBera test incorporated in table (1) indicating the normality of data used in this study for all the three ECO (Pakistan, Iran and Turkey) countries.

Table 1. Descriptive Statistics and Normality Test

\begin{tabular}{cccc}
\hline & For Pakistan & For Turkey & For Iran \\
\hline Mean & -6.153714 & -4.738236 & 3.543615 \\
\hline Median & 7.432964 & -2.314748 & -4.197542 \\
\hline Maximum & 109.2846 & 106.0085 & 59.01285 \\
\hline Minimum & -104.3991 & -153.7022 & -38.47917 \\
\hline Std. Dev. & 52.28473 & 64.50466 & 23.21462 \\
\hline Skewness & -0.121988 & -0.201342 & 0.804739 \\
\hline
\end{tabular}

${ }^{6}$ BT is obtained by adding the foreign trade of ECO countries to each other (among) only (Pakistan, Turkey and Iran).

DE GRUYTER OPEN
Timisoara Journal of Economics and Business | ISSN: 2286-0991 | www.tjeb.ro Year 2016 | Volume 9 | Issue 2 | Pages: 95-114 
Gulzar, A. (2016).

DOES TRADE OPENNESS HAS NOTEWORTHY EFFECT ON BILATERAL TRADE FLOWS OF E.C.O. COUNTRIES; AN EMPIRICAL INVESTIGATION

\begin{tabular}{cccc}
\hline & For Pakistan & For Turkey & For Iran \\
\hline Kurtosis & 2.394527 & 2.802469 & 3.459389 \\
\hline Jarque-Bera & 0.514897 & 0.243084 & 3.385094 \\
\hline Probability & 0.773021 & 0.885554 & 0.184050 \\
\hline Observations & 36 & 36 & 36 \\
\hline
\end{tabular}

The data is also test for unit root by applying Augmented Dicky-Fuller test as unit root and non-stationarity had remains one of the keen suspicious for researchers and economist especially in time series data. The results of ADF test incorporated in table (2) shows that some variables are stationary at $\mathrm{I}(0)$ and some are at $\mathrm{I}(1)$.

Table 2. Unit Root (Augmented Dicky-Fuller) Test Results

\begin{tabular}{ccccccc}
\hline \multirow{2}{*}{ Variables } & \multicolumn{2}{c}{ For Pakistan } & \multicolumn{2}{c}{ For Turkey } & \multicolumn{2}{c}{ For Iran } \\
\cline { 2 - 7 } & At Level & 1st Difference & At Level & 1stDifference & At Level & 1stDifference \\
\hline Bilateral Trade & -1.515662 & $-4.083325^{*}$ & -- & -- & -- & -- \\
\hline Exports & -0.843435 & $-5.713608^{*}$ & -1.807383 & $-6.139153^{*}$ & $-3.736127^{*}$ & $-6.762772^{*}$ \\
\hline Imports & -2.339358 & $-5.207517^{*}$ & $-3.423833^{*}$ & $-5.195161^{*}$ & -2.408032 & $-5.929501^{*}$ \\
\hline Trade Openness & $-3.714832^{*}$ & $-6.263890^{*}$ & -1.716254 & $-4.343162^{*}$ & $-3.282734^{*}$ & $-6.573651^{*}$ \\
\hline Exchange Rate & -1.717455 & $-4.546345^{*}$ & -2.774761 & $-5.716765^{*}$ & -1.372615 & $-4.877385^{*}$ \\
\hline Terms of Trade & -1.037125 & $-3.815054^{*}$ & $-3.638712^{*}$ & $-5.363532^{*}$ & -1.913876 & $-3.892853^{*}$ \\
\hline
\end{tabular}

(*) shows rejection of Null Hypothesis (unit root) at 5\%

It is noticeable that a minor modification in specification or assumptions might greatly influence the outcomes of the unit root test and as a result, a stationary time series might become non stationary series and vice versa (Chowdhury and Shrestha; 2005). Therefore even though if the stationary of the data is determined by the unit root test and every variable is found to be non-stationary, yet there remains a risk of misspecification. From this point of view, ARDL is the most suitable integration technique, as stationarity of variables relies on the various unit root test applied: various approaches could produce differing outcomes that influence the robustness of outcome. Like for instance Pesaran et al (2001), the dependent variable should be integrated of order one however the independent variables could be $\mathrm{I}(0)$ or $\mathrm{I}(1)$.

The major emerging power and economic strength of any developing economy is its exports, as they are the main source of foreign exchange earnings which are necessary for financing imports of a developing country with deficient capital. Similarly imports are also indispensible for establishing local infrastructure and capital formation of an emerging

DE GRUYTER OPEN 
Gulzar, A. (2016).

DOES TRADE OPENNESS HAS NOTEWORTHY EFFECT ON BILATERAL TRADE FLOWS OF E.C.O. COUNTRIES; AN EMPIRICAL INVESTIGATION

economy as well as necessary source of input for manufacturing of exportable. Therefore, trade is a most important determinant of economic growth. Trade pattern and development progression are reciprocal, nature and pattern of trade transforms with phases of development. On the road of development, in beginning an economy typically exports primary commodities and imports consumer goods, however with progression, exports transformed to manufactured goods and imports to machines and technological equipments.

To empirically examine that does trade openness playing any considerable role in bilateral trade flows of ECO countries, the ARDL model that is regressed for regression analysis of the variables data for Pakistan, Turkey and Iran are;

$$
\begin{aligned}
& B T_{t}=\beta_{0}+\beta_{1} X_{t}+\beta_{2} M_{t}+\beta_{3} T O P_{t}+\beta_{4} E R_{t}+\beta_{5} T O T_{t}+\sum_{t-1}^{t=n} \alpha_{0} \Delta B T_{t-1}+\sum_{t-1}^{t=n} \beta_{1} \Delta X_{t-1} \\
& +\sum_{t=1}^{t=n} \beta_{2} \Delta M_{t-1}+\sum_{t=1}^{t=n} \beta_{3} \Delta T O P_{t-1} \sum_{t=1}^{t=n} \beta_{10} \Delta E R_{t-1}+\sum_{t=1}^{t=n} \beta_{13} \Delta T O T_{t-1}+\mu_{t}
\end{aligned}
$$

The above model (4) is regressed by applying ARDL technique for regression analysis of the variables data separately for Pakistan, Turkey and Iran and the results obtained are integrated in table (3). The overall performance of the model is satisfactory as the value of Prob. F-stat is $(0.00000)$ for ECO countries. The value of Durbin-Watson is also very close to the desired value for the entire models and shows negligible chances of serial and autocorrelation in the data. Further, the $\mathrm{R}^{2}$ value for all the model is more than ninety percent indicating that the model successfully explains more than ninety percent variation between dependent and independent variables confirms goodness of fit of the models.

Table 3. Regression Analysis of the Variables Data

\begin{tabular}{cccc}
\hline Variables & For Pakistan & For Turkey & For Iran \\
\hline Constant & $0.145687^{* *}$ & $0.299837^{* *}$ & $0.132731^{*}$ \\
& $(0.062374)$ & $(0.154533)$ & $(0.053214)$ \\
\hline Exports & $0.179591^{*}$ & $0.250543^{* *}$ & $0.122064^{*}$ \\
& $(0.063156)$ & $(0.129158)$ & $(0.078262)$ \\
\hline Imports & $0.192061^{*}$ & $0.278432^{*}$ & $0.149705^{*}$ \\
& $(0.074051)$ & $(0.048608)$ & $(0.084078)$ \\
\hline Trade Openness & $0.172469 *$ & $0.126713^{*}$ & $0.136582^{*}$ \\
& $(0.046321)$ & $(0.067920)$ & $(0.072371)$ \\
\hline
\end{tabular}

\section{DE GRUYTER} OPEN
Timisoara Journal of Economics and Business | ISSN: 2286-0991 | www.tjeb.ro Year 2016 | Volume 9 | Issue 2 | Pages: 95-114 
Gulzar, A. (2016).

DOES TRADE OPENNESS HAS NOTEWORTHY EFFECT ON BILATERAL TRADE FLOWS OF E.C.O. COUNTRIES; AN EMPIRICAL INVESTIGATION

\begin{tabular}{|c|c|c|c|}
\hline Variables & For Pakistan & For Turkey & For Iran \\
\hline Exchange Rate & $\begin{array}{c}-0.112563 * \\
(0.045786)\end{array}$ & $\begin{array}{c}-0.232213 * * \\
(0.059178)\end{array}$ & $\begin{array}{c}0.265076 * * \\
(0.095540)\end{array}$ \\
\hline Terms of Trade & $\begin{array}{c}0.122373 * * \\
(0.053815)\end{array}$ & $\begin{array}{c}0.310126 * * * \\
(0.045171)\end{array}$ & $\begin{array}{c}0.174065 * * * \\
(0.078219)\end{array}$ \\
\hline Lag of $B T_{(-1)}$ & $\begin{array}{l}0.351522 * \\
(0.109295)\end{array}$ & $\begin{array}{c}0.295256 * * * \\
(0.114247)\end{array}$ & $\begin{array}{c}0.365090 * * \\
(0.136532)\end{array}$ \\
\hline R-Squared & 0.978875 & 0.980163 & 0.977431 \\
\hline Adj. R-Squared & 0.974473 & 0.969142 & 0.965768 \\
\hline Durbin Watson & 1.916885 & 1.918600 & 1.894108 \\
\hline Prob. F-Stat & 0.000000 & 0.000000 & 0.000000 \\
\hline
\end{tabular}

$(*),(* *)$ and $(* * *)$ showing significance at 1\%, 5\% \& 10\% respectively.

Trade openness reveals the intensity of foreign trade policies of any economy regarding trade regulations and restriction for the rest of the world. Most of the government regulations especially economic policies are reciprocal. Therefore by imposing some kind of restriction in form of tariffs or quotas by a country to protect domestic industry will restrain other countries to export to the imposing country and will also decrease its imports from the same country. However trade openness or trade liberalization in general is considered to be progressive and beneficial for economic development of any economy but it is constrained by the level and condition of economic growth of any economy. Trade liberalization works in a constructive way if the economy is competent in quality production of much exportable merchandise however for less developed countries that are incompetent in manufacturing sector and relies on conventional agriculture sector and imports from other countries cannot easily grab the advantages of open economy.

As the primary objective of this research study is to empirically examine the role and impact of trade openness on trade flows of ECO countries. The results integrated in table (3) shows that trade openness have positive, momentous and significant effect on bilateral trade flows among the ECO countries. Further, the study also finds that exports, terms of trade and exchange rate also playing an important role in trade flows of these countries.

It is a fact that exports play an important role in economic growth of country with highest potential of employment provision. The economic growths of country in open economies are directly associated to expansion of export and export works as locomotive for economic growth. To meet the requirements of ongoing trends in international market and fashion, indispensible concentration must be paid to this sector. Besides tough competition from international market, this sector also has the capability to make its stand in the world

\section{DE GRUYTER} OPEN 
Gulzar, A. (2016).

market by furnishing this sector with latest technology and by exploring demand trends in different regions. The empirical results obtains from regression analysis of ARDL approach integrated in table (3) shows that exports plays positive and significant role in bilateral trade flows in ECO countries.

Imports of a nation are exports from the rest of the world. Exports by a country are imports for the rest of the international market. Economies import products which are unfeasible or inefficient to produce domestically in other words those products in which the country has comparative disadvantage. While export merchandize in which a country has comparative advantage in its production or have abundant resources to produce it. Imports were considered to be expenditure of an economy's budget in post liberalization era but soon world economies realized the importance and value of imports in accomplishing the requirements of growing economic development. Thus protectionist's policies were sidelined in the interest of economy and promote acknowledgement of technical and resource diffusion from developed economies. Infrastructural and economic growth of developing economies greatly depends upon the imports of machinery and capital inflow from abroad. As most of traditional LDC's are labor intensive economies with inadequate capital therefore to exploit natural resources through labor force, LDC's intensely need to import capital and infrastructural inputs to establish and develop industrial base which is key determinant for development. The empirical results of this study show that imports have also an influential and affirmative role in bilateral trade flows of ECO countries.

Exchange rate or foreign exchange rate is the ratio between the currencies of two countries, or in short it is the value of currency of an economy in terms of another. Foreign exchange rate can be either expressed as value of foreign currency in terms of domestic currency (direct quotation) or as value of domestic currency in terms of foreign currency (indirect quotation). Exchange rate plays vital role in determination of key foreign trade transactions. The results given in table (3) indicate encouraging role of exchange rate in bilateral trade flows of ECO countries.

Terms of trade (TOT) is simply the comparative value of exports in terms of imports and is described as the ratio between prices of export and prices of imports. In other words it is inferred as the quantity imported by an economy against per unit of export merchandise. An improved term of trade is advantageous for the economy, as it can purchase more imports for some certain amount of exports. The terms of trade might be inclined by the exchange rate as an increase in the rate of a economy's currency decrease the import prices domestically however doesn't directly influence the export prices of the country. The

\section{DE GRUYTER} OPEN 
Gulzar, A. (2016).

DOES TRADE OPENNESS HAS NOTEWORTHY EFFECT ON BILATERAL TRADE FLOWS OF E.C.O. COUNTRIES; AN EMPIRICAL INVESTIGATION

empirical results of this study capture the affirmative role of terms of trade in bilateral trade of ECO countries.

Moreover, this study also inspects the long-run relation of variables included in the model by applying the Bound Testing Approach. The Null Hypothesis is $\beta_{1}=\beta_{2}=\beta_{3}=\beta_{4}=\beta_{5}=0$, assuming that there hasn't exists any long-run relation among the variables. In contrast the Alternative Hypothesis showing the existence of long run relation, that is $\beta_{1} \neq 0, \beta_{2} \neq 0, \beta_{3} \neq 0$, $\beta_{4} \neq 0, \beta_{5} \neq 0$. The hypothesis is tested through bound testing approach comparing the F-stat value with Pesaran test values (Pesaran, et. al., 2001). If the F-statistics value is greater than critical value of upper bound assume by Pesaran test, showing rejection of the null hypothesis (Pesaran, et. al., 2001). The result of bound testing approach given in below table (4) shows that long run relation exists between trade openness and bilateral trade flows among the ECO countries.

Table 4. Bound Testing Approach Results (Null Hypothesis: No long-run relationships exist)

\begin{tabular}{cccc}
\hline & For Pakistan & For Turkey & For Iran \\
\hline F-statistic Value & $7.511608^{*}$ & $5.663195^{*}$ & $4.134416^{*}$ \\
\hline IO Bound Value & 2.86 & 2.62 & 2.62 \\
\hline I1 Bound Value & 4.01 & 3.79 & 3.79 \\
\hline
\end{tabular}

(*) shows rejection of Null Hypothesis (unit root) at $5 \%$

\section{Diagnostic and Stability Analysis}

To check the stability and reliability of the models this study applied different stability and diagnostic tests.

To check the serial correlation and Heteroskedasticity, Breusch-Godfrey Serial Correlation LM Breusch-Pagan-Godfrey Heteroskedasticity tests were applied and the results integrated in table (5) and (6) indicate that the model is free from serial correlation and confirming the stability and reliability of the models.

Table 5. Breusch-Godfrey Serial Correlation LM Test Results

\begin{tabular}{lll}
\hline For Pakistan & For Turkey & For Iran \\
\hline
\end{tabular}

DE GRUYTER OPEN
Timisoara Journal of Economics and Business | ISSN: 2286-0991 | www.tjeb.ro Year 2016 | Volume 9 | Issue 2 | Pages: 95-114 
Gulzar, A. (2016).

DOES TRADE OPENNESS HAS NOTEWORTHY EFFECT ON BILATERAL TRADE FLOWS OF E.C.O. COUNTRIES; AN EMPIRICAL INVESTIGATION

\begin{tabular}{cccc}
\hline & For Pakistan & For Turkey & For Iran \\
\hline F-statistic & 0.535411 & 0.022428 & 0.060007 \\
\hline Obs*R-squared & 1.718452 & 0.038209 & 0.108357 \\
\hline Prob. $\mathrm{F}(1,19)$ & 0.5950 & 0.8827 & 0.8096 \\
\hline Prob. Chi-Square(1) & 0.4235 & 0.8450 & 0.7420 \\
\hline
\end{tabular}

Table 6. Breusch-Pagan-Godfrey Heteroskedasticity Test Results

\begin{tabular}{cccc}
\hline & For Pakistan & For Turkey & For Iran \\
\hline F-statistic & $7.511608^{*}$ & $5.663195^{*}$ & $4.134416^{*}$ \\
\hline Obs*R-squared & 2.86 & 2.62 & 2.62 \\
\hline Scaled explained SS & & \\
\hline Prob. F(11,17) & & \\
\hline Prob. Chi-Square(11) & & & \\
\hline Prob. Chi-Square(11) & 4.01 & 3.79 & \\
\hline
\end{tabular}

Further, for the specification error and biasness Ramsey RESET tests were applied and the results incorporated in table (7) shows that the model is free from specification error.

Table 7. Ramsey RESET Test Results

\begin{tabular}{ccccccc}
\hline & \multicolumn{2}{c}{ For Pakistan } & \multicolumn{2}{c}{ For Turkey } & \multicolumn{2}{c}{ For Iran } \\
\cline { 2 - 7 } & \multicolumn{2}{c}{ Value } & Probability & Value & Probability & \multicolumn{2}{c}{ Value } & Probability \\
\hline t-statistic & 1.679187 & 0.1376 & 1.214387 & 0.1735 & 0.905988 & 0.3748 \\
\hline F-statistic & 1.89479 & 0.1376 & 1.788702 & 0.1735 & 1.632791 & 0.3748 \\
\hline
\end{tabular}

\section{Conclusion and Policy Recommendations}

The primary objective of the study is to empirically examine the role of trade openness on bilateral trade flows of ECO countries that are closely connected by socially, politically, economically, religiously, culturally and with many terms and agreements. The study found that trade liberalization has momentous effect on the bilateral trade flows of these countries and concluded that these countries needs to make strong alliance of trade among each other. Further, trade specialization and trade integration with skilled labor and technical transfer is needed to get maximum fruits from trade openness. Moreover, the

DE GRUYTER OPEN
Timisoara Journal of Economics and Business | ISSN: 2286-0991 | www.tjeb.ro

Year 2016 | Volume 9 | Issue 2 | Pages: 95-114 
Gulzar, A. (2016).

empirical results also showed that exports, imports, exchange rate and terms of trade has also positive and significant role in bilateral trade flows of ECO countries.

Trade policies and trade openness takes an important part and focusing analysis from several decades in developing countries. Due to sharp increase in economic growth of many developing countries after adopting trade liberalization policies majority of low economic growth and developing countries coincides their hopes for rapid economic growth with trade openness and trade policies. Trade policies may boom and speed up the process of economic growth that leads to economic development of that country. As trade liberalization is considered as "an engine of economic growth", that's why ECO countries too keeping the importance of trade liberalization had adopted and exercised different trade policies to gain maximum fruits from foreign trade.

Globalization of world economies and world trade brought the foreign trade of ECO countries under tough competition, with speedy developments in technology and modernism, each country has to maintain its standards in accord with the rest of the world industries. It is immense need of any economy to focus on modification structural and policy measures to flourish industry and stand in competition with world market standards. Available resources of ECO countries should be utilized in such an efficient way so that human capital and prevailing economic determinants can be adjusted to bring about required structural transformation of industry for acceleration of the export industry and thus foreign exchange reserves.

\section{Policy Recommendations}

A country's economic development and stand in the world economies can be fairly judge by its contribution in international trade, or it is worth saying that contribution in international trade is the indicator of an economy's performance and its level of fabrication. From the empirical analysis of the bilateral trade flows, this study recommends following suggestion that may bring significant increase in the exports of these countries that will lead to decrease in trade deficit and an augment to growth of ECO countries.

- To reform its custom and trade procedures by focusing on diminishing time and cost of trade transaction.

- To provide a suitable atmosphere for international trade practices following World Custom Organization (WCO) Framework of Standards.

\section{DE GRUYTER} OPEN 
Gulzar, A. (2016).

- There is need of an incorporated, online, automatic, immediate functioning system to effectively work for Customs clearance.

- Public-Private Partnership (PPP) envisages assimilating all stakeholders concerned with international trade and the logistic supply chain.

- Facilitates public sector organizations as well as private sector trade bodies dealing with commerce and industry for customs, trade, transport, insurance and finance activities.

- To encourage implementation of standard international codes of trade and transport terminologies for trade and transport legislation as an effort to be in equivalence with the best of the world.

- To improve export competitiveness, speed up industrialization and maintain the high economic growth and to significantly decrease the expenses of doing trade and commerce in ECO countries.

- Considerable efforts need to explore the markets for trade of ECO production in the world market.

- To support trade logistics by systematic modification of infrastructure and services.

- Restrictions on inflow and outflow of capital need to be minimized or removed to promote foreign direct investment among ECO countries.

- Need of free floating foreign exchange system determined by market forces.

\section{References}

Achay, L. (2006). Assessing Regional Integration in North Africa. National Institute of Statistics and Applied economics, Rabat, Morocco.

Adebiyi, M. A., and Ros, D. (2006). Trade Liberalization Policy and Industrial Growth Performance in Nigeria: An Error Correction Mechanism Technique. The Nigerian Journal of Economic and Social Studies 42 (1): 1 - 22

Ahmed, M. (2010). Openness, Institutions, and Economic Growth: Empirical Evidence from Panel Estimation. North Carolina State University.

Burger, M., Frank van, O., and Gert-Jan, L. (2009). On the Specification of the Gravity Model of Trade: Zeros, Excess Zeros and Zero-Inflated Estimation. Spatial Economic Analysis, 4(2), 167-190.

Chowdhury, M. K. and Shrestha, M. (2005). A Sequential Procedure for Testing Unit Roots in the Presence of Structural Break in Time Series Data: An application to Quarterly Data in Nepal, 1970-2003. International Journal of Applied Econometrics and Quantitative Studies, 2 (2), 1-16.

Dritsaki, C., and Adamopoulos, A. (2005). A Causal Relationship and Macroeconomic Activity: Empirical Results from European Union. American Journal of Applied Sciences, 2 (2), 504-507.

DE GRUYTER OPEN 
Gulzar, A. (2016).

DOES TRADE OPENNESS HAS NOTEWORTHY EFFECT ON BILATERAL TRADE FLOWS OF E.C.O. COUNTRIES; AN EMPIRICAL INVESTIGATION

Dritsaki, C., Dritsaki, M., and Adamopoulos, A. (2004). A Causal Relationship between Trade, Foreign Direct Investment and Economic Growth for Greece. American Journal of Applied Sciences, 1 (3), 230-235.

Dritsaki, C., Vazakides, A., and Adamopoulos, A. (2004). Exports, Investments and Economic Growth: An Empirical Investigation of the Three Baltic Countries. Baltic Journal of Economics, 4 (2), 72-79.

Dritsakis, N. (2004). Exports, Investments and Economic Development of Pre-Accession Countries of the European Union; an Empirical Investigation of Bulgaria and Romania. Applied Economics 36 (16), 1831-1838.

Elshehawy, A. M., Shen, H., and Ahmed A. R. (2014). The Factors Affecting Egypt's Exports: Evidence from the Gravity Model Analysis. Open Journal of Social Sciences, 2 (11), 138-148.

Erdem, K., and Nazliglu, S. (2008). Gravity Model of Turkish Agricultural Exports to the European Union. International Trade and Finance Association Working Papers 2008.

Hsin-Yi, L. (2010). Openness and inflation revisited. International Research Journal of Finance and Economics, Issue 37, 40-45.

Khan, H., and Bashir, K. M. R. O. (2007). Liberalization and Growth: An Econometric Study of Bangladesh. Global Working Paper No. 001/2007.

Kolstad, I. (2009). The Resource Curse: Which Institutions Matter? Applied Economics Letters, 16 (4), 439-442

Malik, S., and Chaudhary, A. R. (2012). The Structure and Behavior of Pakistan's Imports from Selected Asian Countries: An Application of Gravity Model. Pakistan Journal of Social Science, 6 (1), 53-66.

Mehlum, H., Moene, K. and Torvik, R. (2006). Institutions and the Resource Curse. The Economic Journal, 116, 1-20.

Mercan, M., Gocer, I., Sahin, S. B., and Dam, D. (2013). The Effect of Openness on Economic Growth for BRIC-T Countries: Panel Data Analysis. Eurasian Journal of Business and Economics, 6 (11), 1-14.

Pesaran, M. H., Shin, Y., and R. J. Smith. (2001). Bounds Testing Approaches to the Analysis of Level Relationships. Journal of applied econometrics, 16(3), 289326.

Ravallion, M. (2004). Pro-Poor Growth: A Primer. World Bank Policy Research Wprking Paper No. 3242, 1-28.

Santos, S., Joao, M. C. and Tenreyro, S. (2006). The Log of Gravity. Review of Economics and Statistics 88(4), 641-658.

Shaista, K., Ihtisham- ul-Haq., and Dilawar, K. (2013). An Empirical Analysis of Pakistan's Bilateral Trade: A Gravity Model Approach. The Romanian Economic Journal, 4 (8), 103-120.

Tabari, Y. A. N., and Haghight, S. (2014). Iran's Regional Trade and Real Exchange Rate (Gravity Panel Data Models). International Journal of Economy, Management and Social Sciences, 3 (1), 113-117

Thai, T. D. (2006). A Gravity Model for Trade between Vietnam and Twenty-Three European Countries. Department of Economics and Society, Dalarna University, Sweden.

DE GRUYTER OPEN 
Gulzar, A. (2016).

DOES TRADE OPENNESS HAS NOTEWORTHY EFFECT ON BILATERAL TRADE FLOWS OF E.C.O. COUNTRIES; AN EMPIRICAL INVESTIGATION

Ulasan, B. (2012). Openness to International Trade and Economic Growth: A CrossCountry Empirical Investigation. Discussion Paper No. 2012-25.

Vedpal, B., and Sudesh, S. (2004). An Empirical Investigation of the Causal Relationship between Openness and Economic Growth in India. The Asian Economic Review, 49 (1), 485-495.

Zaman, K., Qaiser, A., Adnan, K., and Zahid, A. (2010). Empirical Evidence of Trade Integration between Pakistan and Turkey (A Gravity Approach). Journal of Managerial Sciences, 4(2), 106-114. 